\title{
A Clinical, Radiographic and Laboratory Evaluation of Prognostic Factors in 363 Patients with Malignant Pleural Mesothelioma
}

\author{
Abdullah Cetin Tanrikulu a Abdurrahman Abakay ${ }^{a}$ Mehmet Ali Kaplan ${ }^{b}$ \\ Mehmet Küçüköner $^{b} \quad$ Yilmaz Palancid $^{d}$ Osman Evliyaoglu ${ }^{c}$ Cengizhan Sezgi ${ }^{a}$ \\ Hadice Sen $^{a}$ Ali İhsan Carkanat ${ }^{a}$ Gokhan Kirbas $^{a}$ \\ Departments of ${ }^{a}$ Chest Disease, ${ }^{b}$ Medical Oncology, ${ }^{c}$ Biochemistry, and ${ }^{d}$ Public Health, Medical Faculty, \\ Dicle University, Diyarbakir, Turkey
}

\section{Key Words}

Asbestos exposure • Malignant pleural mesothelioma •

C-reactive protein

\begin{abstract}
Background: Malignant pleural mesothelioma (MPM) has a poor prognosis. Objectives: Only few studies in literature investigated the presence of pleural fluid and radiographic findings for the prognosis of MPM. Methods: We retrospectively investigated the hospital charts of 363 MPM patients who were diagnosed from January 1989 to March 2010. Survival time was calculated by the Kaplan-Meier method. Pretreatment clinical, laboratory and radiographic features of each patient at the time of diagnosis were obtained from patients' charts. Results: The mean age of 363 patients (217 men, 146 women) was $50.6 \pm 11.2$ years (range 19-85) and the mean survival time was $11.7 \pm 8.6$ months (range 1-53). Histological types of MPM were epithelial (71.2\%), mixed (15.9\%) and sarcomatous type (4.9\%). The frequency of disease stages were $31.4 \%$ for stage $1,24.2 \%$ for stage $2,28.6 \%$ for stage 3 and $15.8 \%$ for stage 4 . The most frequent symptoms were dyspnea (82.1\%), chest pain (68.3\%) and weight loss (58.9\%). Results of univariate and multivariate analyses revealed that a Karnofsky performance score $\leq 60$, a pleural fluid glucose level $\leq 40 \mathrm{mg} / \mathrm{dl}$, a C-reactive protein level $>50$
\end{abstract}

$\mathrm{mg} / \mathrm{l}$, a serum lactate dehydrogenase level $>500 \mathrm{U} / \mathrm{l}$, the presence of pleural fluid, pleural thickening $>1 \mathrm{~cm}$ and a platelet count of $>420 \times 10^{3} / \mu$ l were found to be associated with poor prognosis in MPM. Conclusions: Our data suggest that low pleural fluid glucose and high C-reactive protein, the presence of pleural fluid and pleural thickening were associated with poor MPM prognosis. Further prospective studies are needed to highlight prognostic factors more clearly.

Copyright $\odot 2010$ S. Karger AG, Basel

\section{Introduction}

Malignant pleural mesothelioma (MPM) is a cancer basically originating from the pleura, although the pericardium, peritoneum or tunica vaginalis may be affected. The strong relationship between asbestos exposure and MPM has been recognized in the early 1960s [1, 2]. It is generally caused by environmental and occupational asbestos exposure. Also, asbestos, erionite and natural fibrous zeolite, which can be found in volcanic tuffs, have been shown to induce mesothelioma. MPM due to environmental exposure to asbestos and erionite is a relatively common pleural cancer in some areas of Turkey [3-6].

\section{KARGER}

Fax +41613061234 E-Mail karger@karger.ch www.karger.com



Abdullah Cetin Tanrikulu

Department of Chest Diseases, School of Medicine, Dicle University

Diyarbakir (Turkey)

Tel. +90 412248 001, Fax +90 4122488523

E-Mail cetintanrikulu@ hotmail.com 
MPM is a fatal malignancy resistant to most of the current therapeutic drugs. However, some patients may respond to chemotherapy, radiotherapy or immunotherapy, and fewer selected patients may obtain benefit from radical surgery and multimodality treatment $[7,8]$. The median survival for MPM was reported to be about 1 year [9-12]. Current standard first-line chemotherapy in MPM treatment consists of cisplatin and pemetrexed [13]. In one multicenter trial, it was claimed that trimodality therapy with neoadjuvant pemetrexed plus cisplatin is feasible with a reasonable long-term survival rate, particularly for patients who completed all therapies [14].

Several studies on MPM epidemiology, clinical and radiological features were published. However, there is no study on prognostic markers of MPM in our region [1517]. The southeastern region of Turkey has a volcano, Mount Karacadag, and thus, asbestos-related diseases are common in our region [15-17].

Patients can be divided based on prognostic features, including a good or poor prognosis group. Most patients with a poor prognosis survive $<4$ months after diagnosis. Two-year survival ranges between 0 and $10 \%$ in MPM patients $[8,18,19]$.

In several studies, the effects of clinical and laboratory parameters on MPM prognosis have been well investigated, but the contribution of pleural fluid and radiologic features on MPM prognosis has not been studied well enough $[3,8,11,18-21]$.

In this study, we aimed to investigate the effects of various pretreatment clinical and laboratory characteristics on the survival of patients with MPM, which has not been examined previously in our region.

\section{Materials and Methods}

\section{Patients}

A retrospective analysis was performed on the clinical, laboratory and radiological data of 363 patients with MPM who were registered and followed up in our hospital from January 1989 to March 2010. The local ethical committee approved the study protocol. Histological evaluation was performed on either surgical and/or necropsy material and patients with histologically proven MPM were included. Histochemical or immunohistochemical stains were used if necessary. Certain laboratory, clinical and radiographic variables were defined as potential prognostic factors and measured at the time of diagnosis.

After histopathological diagnosis, stage was determined. Chest, cranial and abdominal computed tomography (CT) was performed, and CT scan images were evaluated by a radiologist. Because some patients did not allow thoracoscopy, MPM staging was done according to the Butchart staging system [22].
Pleural effusion was evaluated at time of diagnosis and before pleurodesis was performed. All of the pleural fluids were exudates. We confirmed the presence of pleural fluid when pleural fluid was seen on chest radiography or when pleural fluid thickness was $>0.5 \mathrm{~cm}$ on chest ultrasonography.

The following pretreatment characteristics were evaluated for prognostic evaluation. We registered clinical and laboratory characteristics, such as age ( $\leq 60$ or $>60$ years), gender, asbestos exposure (yes or no), disease location (right, left, bilateral), histopathological subtype (epithelial or others), symptom duration ( $\leq 6$ or $>6$ months), smoking history (yes or no), Karnofsky performance score (KPS, $\leq 60$ or $>60$ ), stage (stage I-II or stage III-IV), presence of chest pain, dyspnea, weight loss ( $>5 \%$ in the last 3 months), pleural effusion, platelet count $(\leq 420,000$ or $>420,000 / \mu \mathrm{l})$, white blood cell (WBC) count $(\leq 11,300$ or $>11,300 / \mu \mathrm{l})$, hemoglobin concentration $(<12.30$ or $\geq 12.30 \mathrm{~g} / \mathrm{dl})$, levels of serum and pleural effusion lactate dehydrogenase ( $\mathrm{LDH}, \leq 500$ or $>500 \mathrm{U} / \mathrm{l})$, serum alkaline phosphatase (ALP, $\leq 79$ or $>79 \mathrm{U} / 1$ ), concentrations of pleural fluid glucose ( $\leq 40$ or $>40 \mathrm{mg} / \mathrm{dl}$ ), C-reactive protein (CRP, $\leq 50$ or $>50 \mathrm{mg} / \mathrm{l}$ ) level, and pleural thickening defined on the chest CT (measurement was done of thickest pleural area $\leq 1$ or $>1 \mathrm{~cm}$ ). In this study, median values of laboratory measurements were used for statistical analysis.

Most of our patients had environmental asbestos exposure, were young and only 32 patients were $>70$ years of age. Therefore, the cut-off for age was set at 60 years. Pleural fluid was obtained from 330 patients.

\section{Statistical Analysis}

Mean values and standard deviation were calculated for continuous variables. The normality of the variables was analyzed by the Kolmogorov-Smirnov test. Duration of survival, median and mean event times with $95 \%$ confidence intervals (CIs) were estimated according to the Kaplan-Meier method. Duration of survival was defined as the period between the time of diagnosis and the time of death, or if patients were still alive, survival was defined as the period between the time of diagnosis and March 2010.

The proportional hazards regression model with stratification for the clinical trial was used for both univariate and multivariate analyses. Univariate analyses examined the prognostic importance of all factors mentioned above. The Cox proportional hazards model was used to examine variables. A 2-sided test was used, with a 0.05 level of significance. Comparisons for overall survival were made using 2 -tailed log-rank tests. Only variables with p values $<0.05$ in univariate analysis were taken into the final model for multivariate analysis.

In the Cox regression analysis, the 'backward conditional' method was used. Significance was taken as $\mathrm{p}<0.05$. Of all patients, 26 were alive during this study. Statistical analyses were performed using SPSS statistical program version 11.

\section{Results}

\section{Patient Characteristics}

A total of 363 patients [217 (60\%) men, 146 (40\%) women] with a mean age of $50.6 \pm 11.2$ years (range 19-85) were included. Environmental asbestos exposure was de- 
1

Fig. 1. Kaplan-Meier survival curves according to the presence of pleural fluid ( $\mathrm{p}<0.001 ; \mathrm{n}=353)$.

Fig. 2. Kaplan-Meier survival curves according to the presence of pleural thickening $(\mathrm{p}<0.001 ; \mathrm{n}=353)$.

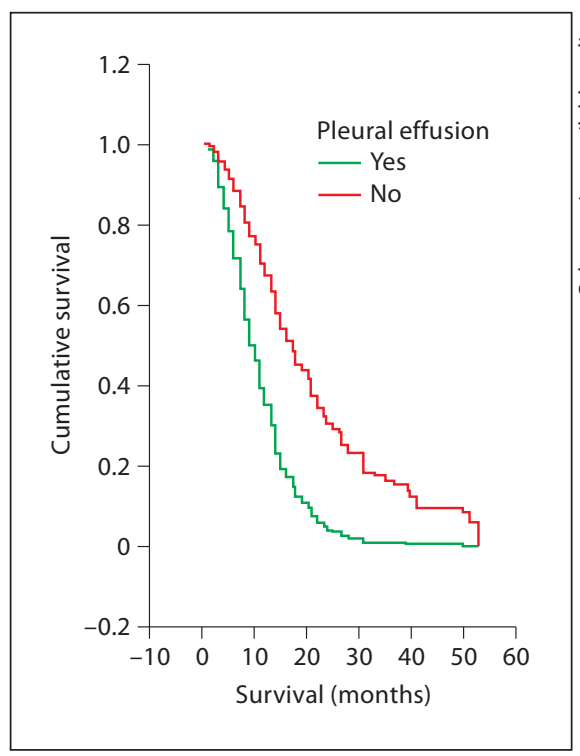

2

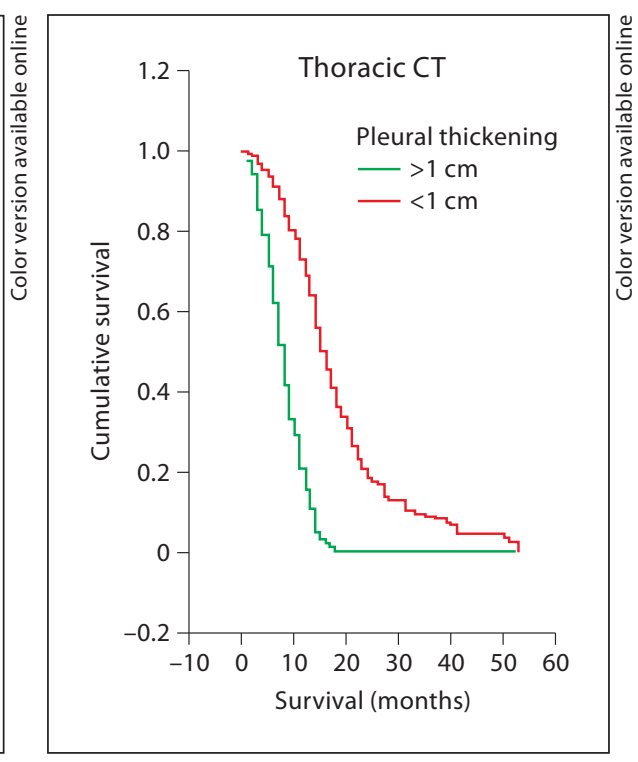

Table 1. Demographic features of MPM patients

\begin{tabular}{|c|c|c|}
\hline Features & $\mathrm{n}$ & $\%$ \\
\hline Patients & 363 & 100 \\
\hline \multicolumn{3}{|l|}{ Gender } \\
\hline Male & 217 & 60 \\
\hline Female & 146 & 40 \\
\hline Asbestos exposure & 309 & 85.1 \\
\hline \multicolumn{3}{|l|}{ Primary site of disease } \\
\hline Right & 220 & 60.6 \\
\hline Left & 119 & 32.7 \\
\hline Bilateral & 24 & 6.7 \\
\hline \multicolumn{3}{|l|}{ Symptoms at diagnosis } \\
\hline Dyspnea & 298 & 82.1 \\
\hline Chest pain & 248 & 68.3 \\
\hline Weight loss & 214 & 58.9 \\
\hline Current smokers $(\mathrm{n}=363)$ & 160 & 44.1 \\
\hline Positive cytology in pleural effusion $(\mathrm{n}=312)$ & 102 & 32.7 \\
\hline \multicolumn{3}{|l|}{ Type of MPM } \\
\hline Epithelial & 258 & 71.2 \\
\hline Mixed & 58 & 15.9 \\
\hline Unidentified & 29 & 7.9 \\
\hline Sarcomatous & 18 & 4.9 \\
\hline \multicolumn{3}{|l|}{ Stage of disease } \\
\hline Stage 1 & 114 & 31.4 \\
\hline Stage 2 & 88 & 24.2 \\
\hline Stage 3 & 104 & 28.6 \\
\hline Stage 4 & 57 & 15.8 \\
\hline
\end{tabular}

tected in $85.1 \%$ of the patients, and the mean exposure duration was $32.5 \pm 14.9$ years. Histological types of MPM were epithelial in $71.2 \%$ of patients, mixed type in $15.9 \%$ and sarcomatous type in $4.9 \%$. The primary site of disease was right in $60.6 \%$, left in $32.7 \%$ and bilateral in $6.7 \%$ of patients. The frequency of disease stage was as follows: stage 1 in $31.4 \%$, stage 2 in $24.2 \%$, stage 3 in $28.6 \%$ and stage 4 in $15.8 \%$ of patients. The most frequent symptoms were dyspnea (82.1\%), chest pain (68.3\%) and weight loss (58.9), and the mean duration of symptoms was 5.5 \pm 4.8 months. The mean KPS was 62.8 (range 50-80) (table 1).

Diagnostic methods were closed pleural biopsy in 250 (70.8\%) patients and open pleural biopsy in 103 (29.2\%). The mean erythrocyte sedimentation rate was $69.7 \pm$ $21.9 \mathrm{~mm} / \mathrm{h}$.

Peritoneal invasion was detected in 12 and pericardial invasion in 2 patients. The mean survival time was 11.7 \pm 8.6 months (range $1-53$ ).

\section{Univariate Analyses}

Twenty-two parameters that we expected to be associated with prognosis were used in univariate analysis. Significant poor prognostic factors were nonepithelial histological subtype, positive smoking history, KPS $\leq 60$, disease stage III-IV, presence of chest pain, platelet count $>420,000 / \mu \mathrm{l}$, WBC count $>11,300 / \mu \mathrm{l}$, level of hemoglobin $<12.30 \mathrm{~g} / \mathrm{dl}$, serum and pleural $\mathrm{LDH}>500 \mathrm{U} / \mathrm{l}$, serum ALP $>79 \mathrm{U} / \mathrm{l}, \mathrm{CRP}>50 \mathrm{mg} / \mathrm{l}$, pleural fluid glucose $\leq 40$ $\mathrm{mg} / \mathrm{dl}$, presence of pleural effusion, and pleural thicken- 
Table 2. Result of univariate analysis for potential prognostic patient characteristics

\begin{tabular}{|c|c|c|c|c|c|c|c|c|c|c|c|}
\hline Variable & $\mathrm{O} / \mathrm{N}^{1}$ & $\%$ & $\begin{array}{l}\text { Median } \\
\text { survival } \\
\text { months }\end{array}$ & $95 \%$ CI & $\begin{array}{l}\mathrm{p} \\
\text { value }\end{array}$ & Variable & $\mathrm{O} / \mathrm{N}^{1}$ & $\%$ & $\begin{array}{l}\text { Median } \\
\text { survival } \\
\text { months }\end{array}$ & $95 \%$ CI & $\begin{array}{l}\mathrm{p} \\
\text { value }\end{array}$ \\
\hline Age & & & & & & Hemoglobin & & & & & \\
\hline$\leq 60$ years & $245 / 262$ & 0.95 & 11.8 & $13.02-14.98$ & 0.158 & $>12.30 \mathrm{~g} / \mathrm{dl}$ & $193 / 200$ & 0.96 & 11.00 & $10.07-11.93$ & 0.319 \\
\hline$>60$ years & $92 / 101$ & 0.93 & 8.8 & $6.98-11.02$ & & $\leq 12.30 \mathrm{~g} / \mathrm{dl}$ & $144 / 163$ & 0.92 & 8.00 & $6.69-9.31$ & \\
\hline Gender & & & & & & Platelet count & & & & & \\
\hline Male & $203 / 217$ & 0.95 & 9.30 & $8.03-10.97$ & 0.328 & $\leq 420 \times 10^{3} / \mu \mathrm{l}$ & $150 / 162$ & 0.97 & 14.00 & $13.21-14.79$ & 0.000 \\
\hline Female & $134 / 146$ & 0.93 & 10.00 & $8.53-11.47$ & & $>420 \times 10^{3} / \mu \mathrm{l}$ & $187 / 201$ & 0.92 & 7.00 & $6.26-7.74$ & \\
\hline Asbestos exposure & & & & & & WBC count & & & & & \\
\hline Present & $290 / 309$ & 0.95 & 10.00 & $9.02-10.98$ & 0.172 & $\leq 11,300 / \mu \mathrm{l}$ & $238 / 259$ & 0.94 & 11.00 & $9.70-12.30$ & 0.019 \\
\hline Absent & $47 / 54$ & 0.90 & 10.00 & $6.59-13.41$ & & $>11,300 / \mu \mathrm{l}$ & $99 / 104$ & 0.94 & 9.00 & $7.24-10.76$ & \\
\hline Smoking & & & & & & ALP & & & & & \\
\hline Never & $150 / 159$ & 0.96 & 10.50 & $8.54-12.46$ & 0.007 & $\leq 79 \mathrm{U} / \mathrm{l}$ & $144 / 157$ & 0.92 & 14.00 & $13.03-14.97$ & 0.000 \\
\hline Ever & $187 / 204$ & 0.93 & 9.00 & $7.53-10.47$ & & $>79 \mathrm{U} / \mathrm{l}$ & $193 / 206$ & 0.96 & 8.00 & $7.28-8.72$ & \\
\hline Stage & & & & & & Pleural fluid glucose & & & & & \\
\hline I-II & $179 / 202$ & 0.90 & 14.00 & $13.07-14.92$ & 0.000 & $\leq 40 \mathrm{mg} / \mathrm{dl}$ & $183 / 189$ & 0.97 & 8.00 & $7.51-8.49$ & 0.000 \\
\hline III-IV & $158 / 161$ & 0.99 & 7.00 & $6.29-7.71$ & & $>40 \mathrm{mg} / \mathrm{dl}$ & $126 / 141$ & 0.89 & 14.00 & $12.53-15.47$ & \\
\hline KPS & & & & & & Pleural fluid $\mathrm{pH}$ & & & & & \\
\hline$<60$ & $167 / 173$ & 0.98 & 7.00 & $6.40-7.60$ & 0.000 & $>7.2$ & $157 / 169$ & 0.97 & 14.00 & $12.99-15.01$ & 0.000 \\
\hline$\geq 60$ & $170 / 190$ & 0.91 & 15.00 & $13.95-16.05$ & & $\leq 7.2$ & $152 / 161$ & 0.92 & 7.00 & $6.30-7.70$ & \\
\hline Histopathological type & & & & & & Pleural thickening o & horacic CT & & & & \\
\hline Epithelial & $241 / 258$ & 0.93 & 11.00 & $9.88-12.12$ & 0.018 & $\leq 1 \mathrm{~cm}$ & $138 / 150$ & 0.93 & 17.00 & $15.37-18.63$ & 0.000 \\
\hline Others & $96 / 105$ & 0.96 & 8.00 & $6.13-9.87$ & & $>1 \mathrm{~cm}$ & $199 / 213$ & 0.95 & 7.00 & $6.42-7.58$ & \\
\hline Pleural fluid cytology & & & & & & CRP & & & & & \\
\hline Positive & $98 / 102$ & 0.99 & 9.00 & $7.47-10.53$ & 0.212 & $\leq 50 \mathrm{mg} / \mathrm{l}$ & $114 / 134$ & 0.87 & 17.00 & $15.20-18.80$ & 0.000 \\
\hline Negative & $239 / 261$ & 0.92 & 11.00 & $9.53-12.47$ & & $>50 \mathrm{mg} / \mathrm{l}$ & $223 / 229$ & 0.98 & 8.00 & $7.36-8.64$ & \\
\hline Duration of symptoms & & & & & & Pleural effusion & & & & & \\
\hline$\leq 6$ months & $204 / 216$ & 0.96 & 10.00 & $8.67-11.33$ & 0.955 & Yes & $310 / 330$ & 0.94 & 9.00 & $8.02-9.98$ & 0.000 \\
\hline$>6$ months & $133 / 147$ & 0.92 & 11.00 & $9.29-12.71$ & & No & $27 / 33$ & 0.98 & 20.00 & $16.18-23.82$ & \\
\hline Chest pain & & & & & & Serum LDH level & & & & & \\
\hline Ever & $234 / 248$ & 0.95 & 8.1 & $9.15-12.85$ & 0.013 & $\leq 500 \mathrm{U} / 1$ & $93 / 101$ & 0.97 & 13.00 & $12.11-13.89$ & 0.000 \\
\hline Never & $104 / 115$ & 0.91 & 9.5 & $8.77-11.23$ & & $>500 \mathrm{U} / 1$ & $244 / 262$ & 0.93 & 6.00 & $5.31-6.69$ & \\
\hline Dyspnea & & & & & & Pleural fluid LDH & & & & & \\
\hline Ever & $274 / 298$ & 0.93 & 10.00 & $8.90-11.10$ & 0.086 & $\leq 500 \mathrm{U} / 1$ & $116 / 126$ & 0.89 & 13.50 & $12.52-14.48$ & 0.000 \\
\hline Never & $63 / 65$ & 0.98 & 12.00 & $9.89-14.12$ & & $>500 \mathrm{U} / \mathrm{l}$ & $193 / 204$ & 0.97 & 8.00 & $7.51-8.49$ & \\
\hline \multicolumn{12}{|l|}{ Weight loss } \\
\hline Ever & $207 / 214$ & 0.98 & 10.00 & $8.83-11.17$ & 0.065 & & & & & & \\
\hline Never & $130 / 149$ & 0.88 & 11.00 & $9.55-12.45$ & & Obse & Imber/ & the & umber. & & \\
\hline
\end{tabular}

ing $>1 \mathrm{~cm}$ ( $\mathrm{p}<0.05$ for each variable). Variables with $\mathrm{p}<$ 0.05 in univariate analysis were taken into the final model for multivariate analysis (table 2).

No associations were found between MPM prognosis and age, gender, asbestos exposure, pleural fluid cytology, duration of symptoms, presence of dyspnea, weight loss and level of hemoglobin ( $p>0.05$ for each variable) (table 2).

\section{Multivariate Analyses}

According to multivariate analysis results, a KPS $\leq 60$ increased poor prognosis 2.25 times, pleural fluid glucose level $\leq 40 \mathrm{mg} / \mathrm{dl} 1.73$ times, CRP $>50 \mathrm{mg} / \mathrm{l} 1.56$ times, serum LDH $>500 \mathrm{U} / 12.24$ times, presence of pleural fluid 2.90 times, pleural thickening $>1 \mathrm{~cm} 2.15$ times and platelet count $>420 \times 10^{3} / \mu \mathrm{l} 1.33$ times in MPM patients (table 3). Our data and those of previous studies that investigated prognostic factors in MPM are shown in table 4 .

The survival curves of the patients for the presence of pleural effusion, pleural thickening, serum CRP level and pleural effusion glucose level are presented in figures $1-4$. 
3

Fig. 3. Kaplan-Meier survival curves according to the presence of the CRP level $(\mathrm{p}<0.001 ; \mathrm{n}=353)$.

Fig. 4. Kaplan-Meier survival curves according to the pleural glucose level ( $\mathrm{p}<$ $0.001 ; \mathrm{n}=320$ ).
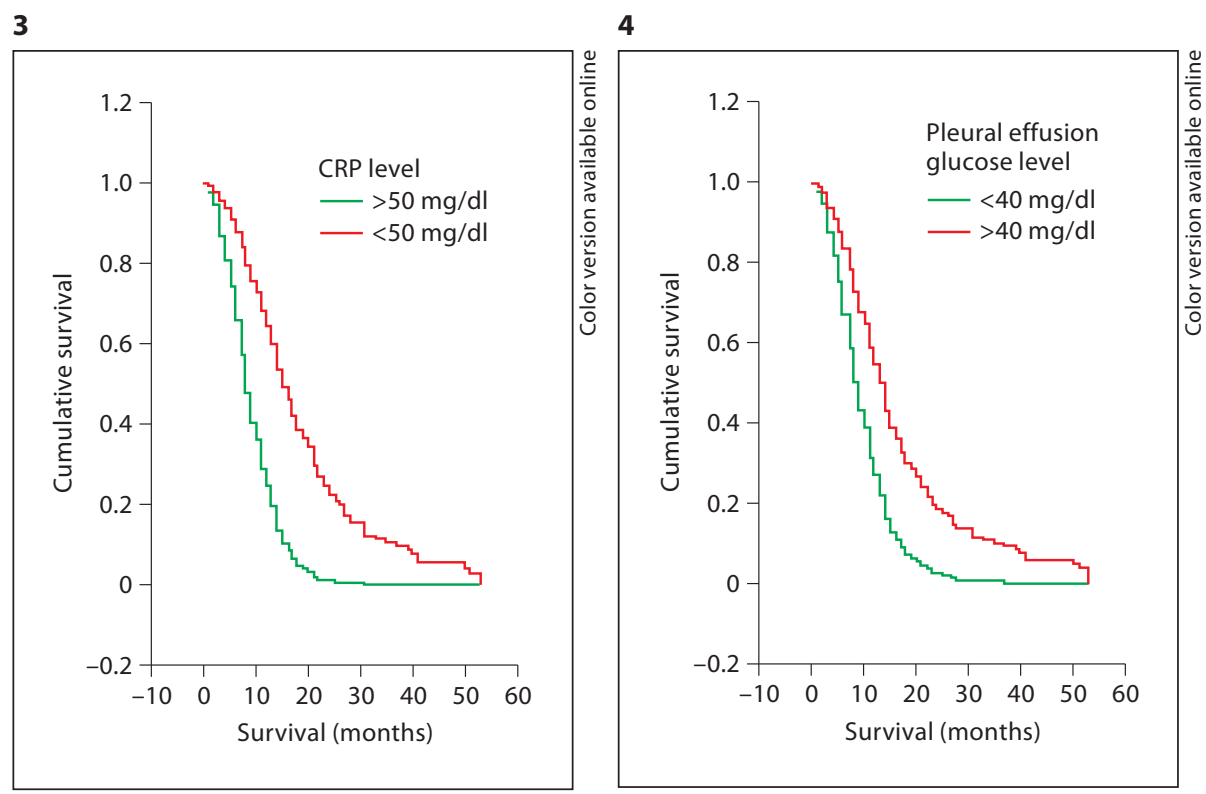

\section{Discussion}

In an asbestos-containing area, exposure to environmental asbestos and erionite starts at birth. Therefore, occupational cases of MPM are seen among an older population. The mean age is around $60-65$ years in patients with occupational exposure [23-25].

In our region, asbestos exposure is mostly environmental [15-17] and begins at birth. Therefore, MPM is detected at earlier ages. In one study performed in this region, the mean age of patients was 52.4 years [15]. The mean age of MPM patients in our study is relatively low, probably as a result of regional environmental asbestos exposure.

In spite of several available treatment regimens, MPM still is a disease with a poor prognosis. The mean survival time of MPM patients is 6-12 months [18-21, 24, 26, 27], and in our study, 12 months.

The Cancer and Leukemia Group B and the European Organization for Research and Treatment of Cancer have analyzed large numbers of patients enrolled in MPM trials and have identified the following poor prognostic factors for MPM [28]: nonepithelioid histology, poor performance status, chest pain, age $>75$ years, male gender, $\mathrm{WBC} \geq 8.3 \times 10^{9} / \mathrm{l}$, platelet number $>400,000 / \mu \mathrm{l}$, and $\mathrm{LDH}>500 \mathrm{IU} / \mathrm{l}$.

In other studies, the prognostic factors associated with MPM were older age [20, 21, 28], male gender [18, 19, 21], advanced stage [18], nonepithelioid histology [18, 19, 21, 26], thrombocytosis [18, 29], higher serum LDH level [20],
Table 3. Multivariate stepwise model

\begin{tabular}{llll}
\hline Variable & $\begin{array}{l}\text { Hazard } \\
\text { ratio }\end{array}$ & $95 \%$ CI & $\begin{array}{l}\mathrm{p} \\
\text { value }\end{array}$ \\
\hline $\begin{array}{l}\text { KPS } \\
\quad \leq 60\end{array}$ & 1 & $1.623-3.118$ & 0.001 \\
$\quad<60$ & 2.25 & & \\
$\begin{array}{l}\text { Pleural fluid glucose level } \\
\quad>40 \mathrm{mg} / \mathrm{dl}\end{array}$ & 1 & $1.222-2.451$ & 0.002 \\
$\quad \leq 40 \mathrm{mg} / \mathrm{dl}$ & 1.73 & & \\
$\begin{array}{l}\text { CRP } \\
\quad \leq 50 \mathrm{mg} / \mathrm{l}\end{array}$ & 1 & $1.139-2.105$ & 0.005 \\
$\quad>50 \mathrm{mg} / \mathrm{l}$ & 1.56 & & \\
$\begin{array}{l}\text { Serum LDH level } \\
\quad \leq 500 \mathrm{U} / \mathrm{l}\end{array}$ & 1 & $1.585-3.168$ & 0.001 \\
$\quad>500 \mathrm{U} / \mathrm{l}$ & 2.24 & & \\
$\begin{array}{l}\text { Pleural effusion } \\
\quad \text { No }\end{array}$ & 1 & $1.869-4.527$ & 0.001 \\
$\quad$ Yes & 2.90 & & \\
$\begin{array}{l}\text { Pleural thickening on chest CT } \\
\quad \leq 1 \mathrm{~cm}\end{array}$ & 1 & $1.520-3.025$ & 0.001 \\
$\quad>1 \mathrm{~cm}$ & 2.15 & & \\
Platelet count & & & \\
$\quad \leq 420 \times 10^{3} / \mu \mathrm{l}$ & 1 & $1.009-1757$ & 0.043 \\
$\quad>420 \times 10^{3} / \mu \mathrm{l}$ & 1.33 & & \\
\hline
\end{tabular}

higher WBC count $[18,19]$, lower hemoglobin level [18] and poor performance status [18-20, 26] (table 4). Prognostic parameters, such as a lower KPS, a higher serum $\mathrm{LDH}$ level and thrombocytosis accepted in literature, were also considered to be prognostic factors in this study. 
Table 4. Suggested prognostic factors for MPM in the present and previous studies

\begin{tabular}{|c|c|c|c|c|c|c|c|c|c|c|}
\hline & This study & $\begin{array}{l}\text { Metintaş } \\
\text { et al. [20] }\end{array}$ & $\begin{array}{l}\text { Curran } \\
\text { et al. [19] }\end{array}$ & $\begin{array}{l}\text { Herndon } \\
\text { et al. [28] }\end{array}$ & $\begin{array}{l}\text { Edwards } \\
\text { et al. [18] }\end{array}$ & $\begin{array}{l}\text { Montanaro } \\
\text { et al. [21] }\end{array}$ & $\begin{array}{l}\text { Borasio } \\
\text { et al. [27] }\end{array}$ & $\begin{array}{l}\text { Gorini } \\
\text { et al. [26] }\end{array}$ & $\begin{array}{l}\text { Spirtas } \\
\text { et al. [29] }\end{array}$ & $\begin{array}{l}\text { Manzini } \\
\text { et al. [31] }\end{array}$ \\
\hline Patients & 363 & 100 & 204 & 337 & 142 & 4,100 & 394 & 381 & 1,475 & 80 \\
\hline Age & - & + & - & + & - & + & - & - & + & - \\
\hline Gender & - & - & + & - & + & + & - & - & + & - \\
\hline Stage & - & + & - & - & - & $\varnothing$ & $\varnothing$ & $\varnothing$ & + & + \\
\hline Smoking & - & - & $\varnothing$ & - & $\varnothing$ & $\varnothing$ & - & $\varnothing$ & $\varnothing$ & $\varnothing$ \\
\hline Histological type & - & - & $\begin{array}{l}+(\text { sarco- } \\
\text { matous })\end{array}$ & $\begin{array}{l}+ \text { (non- } \\
\text { epithelial) }\end{array}$ & $\begin{array}{l}+ \text { (non- } \\
\text { epithelial) }\end{array}$ & + & $\begin{array}{l}+ \text { (non- } \\
\text { epithelial) }\end{array}$ & + & $\varnothing$ & + \\
\hline Dyspnea & - & - & $\varnothing$ & - & $\varnothing$ & $\varnothing$ & $\varnothing$ & $\varnothing$ & $\varnothing$ & - \\
\hline Symptom time & - & $\varnothing$ & $\varnothing$ & - & $\varnothing$ & $\varnothing$ & - (4 months) & $\varnothing$ & $\varnothing$ & - \\
\hline Platelet count & + & - & - & + & - & $\varnothing$ & + & $\varnothing$ & + & - \\
\hline Pleural fluid glucose & + & $\varnothing$ & $\varnothing$ & $\varnothing$ & $\varnothing$ & $\varnothing$ & $\varnothing$ & $\varnothing$ & $\varnothing$ & $\varnothing$ \\
\hline Serum LDH & + & $+(>500 \mathrm{U} / \mathrm{l})$ & - & $+(>500 \mathrm{U} / \mathrm{l})$ & $\varnothing$ & $\varnothing$ & $\varnothing$ & $\varnothing$ & $\varnothing$ & $\varnothing$ \\
\hline Hemoglobin & - & - & - & - & $+(<14 \mathrm{~g} / \mathrm{dl})$ & $\varnothing$ & $\varnothing$ & $\varnothing$ & $\varnothing$ & $\varnothing$ \\
\hline Chest pain & - & - & $\varnothing$ & + & - & $\varnothing$ & - & $\varnothing$ & $\varnothing$ & - \\
\hline Weight loss & - & - & $\varnothing$ & - & - & $\varnothing$ & - & $\varnothing$ & $\varnothing$ & - \\
\hline Performance status & $+($ KPS $<60)$ & $+($ KPS $<70)$ & $+(\mathrm{ECOG})$ & $+(\mathrm{ECOG})$ & $+(\mathrm{ECOG})$ & $\varnothing$ & $+(\mathrm{KPS}<80)$ & $\varnothing$ & $\varnothing$ & - \\
\hline Presence of pleural fluid & + & $\varnothing$ & $\varnothing$ & $\varnothing$ & $\varnothing$ & $\varnothing$ & $\varnothing$ & $\varnothing$ & $\varnothing$ & $-{ }^{1}$ \\
\hline CRP level & + & $\varnothing$ & $\varnothing$ & $\varnothing$ & $\varnothing$ & $\varnothing$ & $\varnothing$ & $\varnothing$ & $\varnothing$ & - \\
\hline Pleural thickening & + & $\varnothing$ & $\varnothing$ & $\varnothing$ & $\varnothing$ & $\varnothing$ & $\varnothing$ & $\varnothing$ & $\varnothing$ & - \\
\hline Pleural LDH level & - & $\varnothing$ & $\varnothing$ & $\varnothing$ & $\varnothing$ & $\varnothing$ & $\varnothing$ & $\varnothing$ & $\varnothing$ & - \\
\hline Pleural fluid cytology & - & $\varnothing$ & $\varnothing$ & $\varnothing$ & $\varnothing$ & $\varnothing$ & $\varnothing$ & $\varnothing$ & $\varnothing$ & $-(\mathrm{ECOG})$ \\
\hline Serum ALP level & - & $\varnothing$ & $\varnothing$ & $\varnothing$ & $\varnothing$ & $\varnothing$ & $\varnothing$ & $\varnothing$ & $\varnothing$ & $\varnothing$ \\
\hline$\overline{\mathrm{WBC} \text { count }}$ & - & $\varnothing$ & + & - & + & $\varnothing$ & $\varnothing$ & $\varnothing$ & $\varnothing$ & $\varnothing$ \\
\hline Pleural fluid $\mathrm{pH}$ & - & $\varnothing$ & $\varnothing$ & $\varnothing$ & $\varnothing$ & $\varnothing$ & $\varnothing$ & $\varnothing$ & $\varnothing$ & $\varnothing$ \\
\hline Primary site of tumor & $\varnothing$ & - & $\varnothing$ & $\varnothing$ & $\varnothing$ & $\varnothing$ & - & $\varnothing$ & $\varnothing$ & - \\
\hline Asbestos exposure & - & - & - & - & - & - & - & - & $\varnothing$ & $\varnothing$ \\
\hline
\end{tabular}

$+=$ Significant $-=$ not significant; $\varnothing=$ not studied; ECOG = Eastern Cooperative Oncology Group.

${ }^{1}$ Presence of pleural fluid and pleural fluid cytology were studied together.

Overall, other studies have not detected any significant correlation between prognosis of MPM and duration of symptom time and symptoms (table 4). In this study, no significant correlations between the prognosis of MPM and the duration of symptom time, dyspnea, weight loss and chest pain were found.

Factors that have not been taken into consideration in earlier prognostic studies and which we thought could have potential effective prognostic value, such as serum ALP level and pleural fluid cytology, did not show any prognostic value.

Previously, a positive pleural fluid cytology was detected in about one third of MPM patients, similar to our results. However, contrary to our study, in other studies, tumor cells in pleural fluid had not been considered a prognostic factor [30].

The prognostic parameters determined to be significant or insignificant as well as their comparison with other large MPM studies are shown in table 4. As can be seen in our study results, the presence of pleural fluid, a high CRP level and pleural thickening were shown to be poor prognostic factors for the first time.

In our study, the presence of pleural fluid was established as a prognostic factor, in contrast with previous studies. We think that the presence of pleural fluid shows invasion of pleural surface by MPM cells, and thus, expansion of this disease into the pleural cavity. In one study, the presence of pleural fluid with mesothelial cells but without neoplastic cells was found to be a favorable prognostic factor. However, in that study, the presences of pleural fluid and pleural fluid cytology were studied together [31]. We believe that the presence of pleural fluid especially with a positive cytology is associated with a poor prognosis.

In a Turkish study on pleural fluid parameters of 71 MPM patients, a lower pleural fluid glucose level was found to be associated with poor prognosis [32]. In another study, performed on 26 patients, to evaluate pleural 
fluid parameters, it was reported that the pleural fluid glucose level and pleural fluid $\mathrm{pH}$ were associated with MPM prognosis [33]. In our study, we found that a lower pleural fluid glucose level was also associated with a poor prognosis of MPM. On the other hand, we could not find any significant relationship between prognosis and pleural fluid $\mathrm{pH}$ and pleural LDH level. MPM cells are using pleural glucose for their metabolic activity. Therefore, in our opinion, lower pleural fluid glucose levels lead to higher activity of MPM and this reflects a poor prognosis.

CRP is an acute-phase reactant, and it is increased in inflammatory cases. In our study, a higher CRP level was correlated with a poor prognosis of MPM. In several prognostic studies carried out on lung cancer patients, a significant relationship was detected between a higher CRP level and a poor prognosis of lung cancer, suggesting that the CRP level could be used as a prognostic marker of lung cancer patients $[34,35]$. To our knowledge, this is the first study to investigate the relationship between CRP and MPM prognosis. The CRP test is inexpensive and can be used for the follow-up of prognosis.

For pulmonary and pleural abnormalities, the most commonly used imaging method is chest CT. In MPM, pleural thickening is the most frequently detected abnormality on chest CT, seen in variable types and sizes [37, 38]. Pleural thickening of more than $1 \mathrm{~cm}$ is a specific MPM finding on chest CT [30]. In this respect, we investigated pleural thickening to find out how it affects MPM survival and found it to be significant. As shown in sev- eral studies, pleural thickening appears to be a remarkable finding of MPM, and an increase in thickening raises the tumor burden in the pleural area. As a result, patients with a thicker pleura have a poorer survival. In one MPM study, an association between the degree of pleural involvement and MPM prognosis was detected during thoracoscopy [27].

One limitation of our study is its retrospective nature. Another limitation is that some markers were not studied. Soluble mesothelin-related peptide, osteopontin and megakaryocyte potentiating factor have been studied for mesothelioma prognosis [39]. These and other promising markers can be studied in new clinical trials.

In conclusion, MPM still is a disease with poor prognosis. We have very few parameters to estimate MPM prognosis, such as pleural fluid glucose, platelet count and WBC counts. The number of studies that have investigated the effect of pleural fluid and radiographic findings on the prognosis of MPM is very limited. In this study, new parameters that could have an effect on MPM prognosis were discussed. Significant predictors of survival include KPS, platelet count, pleural fluid glucose level, serum CRP and LDH level, the presence of pleural fluid and pleural thickening. Understanding the importance of these markers for MPM prognosis should allow targeted treatments to be developed.

Therefore, we believe that studies of large series are needed to investigate the relationship between prognostic markers and treatment regimens.

\section{References}

1 Wagner JC, Sleggs CA, Marchand P: Diffuse pleural mesothelioma and asbestos exposure in the North Western Cape Province. Br J Indust Med 1960;17:266-271.

-2 Greillier L, Astoul P: Mesothelioma and asbestos-related pleural diseases. Respiration 2008;76:1-15.

- 3 Emri S, Akbulut H, Zorlu F, Dinçol D, Akay H, Güngen Y, Içli F: Prognostic significance of flow cytometric DNA analysis in patients with malignant pleural mesothelioma. Lung Cancer 2001;33:109-114.

-4 Bariş B, Demir AU, Shehu V, Karakoca Y, Kisacik G, Bariș YI: Environmental fibrous zeolite (erionite) exposure and malignant tumors other than mesothelioma. J Environ Pathol Toxicol Oncol 1996;15:183-189.

5 Dumortier P, Coplü L, de Maertelaer V, Emri S, Baris I, De Vuyst P: Assessment of environmental asbestos exposure in Turkey by bronchoalveolar lavage. Am J Respir Crit Care Med 1998;158:1815-1824.
6 6 Selçuk ZT, Cöplü L, Emri S, Kalyoncu AF, Sahin AA, Bariș YI: Malignant pleural mesothelioma due to environmental mineral fiber exposure in Turkey. Analysis of 135 cases. Chest 1992;102:790-796.

7 Peto J, Decarli A, La Vecchia C, Levi F, Negri E: The European mesothelioma epidemic. Brit J Cancer 1999;79:666-672.

8 Burgers JA, Damhuis RA: Prognostic factors in malignant mesothelioma. Lung Cancer 2004;45:49-54.

-9 Alberts AS, Falkson G, Goedhals L, Vorobiof DA, Van der Merwe CA: Malignant pleural mesothelioma: a disease unaffected by current therapeutic maneuvers. J Clin Oncol 1988;6:527-535.

10 Vogelzang NJ: Malignant mesothelioma: diagnostic and management strategies for 1992. Semin Oncol 1992;19:64-71.
11 Chailleux E, Dabouis G, Pioche D, de Lajartre M, de Lajartre AY, Rembeaux A, Germaud P: Prognostic factors in diffuse malignant pleural mesothelioma. A study of 167 patients. Chest 1988;93:159-162.

12 Schouwink H, Korse CM, Bonfrer JM, Hart AA, Baas P: Prognostic value of the serum tumour markers Cyfra 21-1 and tissue polypeptide antigen in malignant mesothelioma. Lung Cancer 1999;25:25-32.

13 Vogelzang NJ, Rusthoven JJ, Symanowski J, et al: Phase III study of pemetrexed in combination with cisplatin versus cisplatin alone in patients with malignant pleural mesothelioma. J Clin Oncol 2003;21:2636-2644.

14 Krug LM, Pass HI, Rusch VW, Kindler HL, Sugarbaker DJ, Rosenzweig KE, Flores R, Friedberg JS, Pisters K, Monberg M, Obasaju CK, Vogelzang NJ: Multicenter phase II trial of neoadjuvant pemetrexed plus cisplatin followed by extrapleural pneumonectomy and radiation for malignant pleural mesothelioma. J Clin Oncol 2009;27:3007-3013. 
15 Tanrikulu AC, Senyigit A, Dagli CE, Babayigit $\mathrm{C}$, Abakay A: Environmental malignant pleural mesothelioma in Southeast Turkey. Saudi Med J 2006;27:1605-1607.

-16 Senyiğit A, Bayram H, Babayiğit C, Topçu F, Nazaroğlu H, Bilici A, Leblebici IH: Malignant pleural mesothelioma caused by environmental exposure to asbestos in the Southeast of Turkey: CT findings in 117 patients. Respiration 2000;67:615-622.

-17 Senyiğit A, Babayiğit C, Gökirmak M, Topçu F, Asan E, Coşkunsel M, Ișik R, Ertem M: Incidence of malignant pleural mesothelioma due to environmental asbestos fiber exposure in the southeast of Turkey. Respiration 2000;67:610-614.

- 18 Edwards JG, Abrams KR, Leverment JN: Prognostic factors for malignant mesothelioma in 142 patients: validation of CALGB and EORTC prognostic scoring systems. Thorax 2000;55:731-735.

19 Curran D, Sahmoud T, Therasse P: Prognostic factors in patients with pleural mesothelioma: the European Organisation for research and treatment of cancer experience. J Clin Oncol 1998;16:145-152.

-20 Metintas M, Metintas S, Ucgun I, Gibbs AR, Harmanci E, Alatas F, Erginel S, Tel N, Pasaoglu O: Prognostic factors in diffuse malignant pleural mesothelioma: pretreatment clinical and laboratory characteristics. Respir Med 2001:95:829-835.

-21 Montanaro F, Rosato R, Gangemi M, Roberti S, Ricceri F, Merler E, Gennaro V, Romanelli A, Chellini E, Pascucci C, Musti M, Nicita C, Barbieri PG, Marinaccio A, Magnani C, Mirabelli D: Survival of pleural malignant mesothelioma in Italy: a population-based study. Int J Cancer 2009;124:201217.
22 Butchart EG, Ashcroft T, Barnsley WC, Holden MP: Pleuropneumonectomy in the management of diffuse malignant mesothelioma of the pleura. Experience with 29 patients. Thorax 1976;31:15-24.

23 Walz R, Koch HK: Malignant pleural mesothelioma: some aspects of epidemiology, differential diagnosis and prognosis. Pathol Res Pract 1990;186:124-134.

24 Chapman A, Mulrennan S, Ladd B, Muers MF: Population based epidemiology and prognosis of mesothelioma in Leeds, UK. Thorax 2008;63:435-439.

25 Letourneux M, Galateau F, Legendre C, Leclerc A, Beck A, Launoy G, Raffaelli C, Bazin B: Malignant mesotheliomas diagnosed in Lower Normandy between 1980 and 1990 Eur Respir Rev 1993;3:87-88.

26 Gorini G, De Gregorio G, Silvestri S, Chellini E, Cupelli V, Seniori Costantini A: Survival of malignant pleural mesothelioma cases in the Tuscan Mesothelioma Register, 1988-2000: a population-based study. Eur J Cancer Prev 2005;14:195-199.

27 Borasio P, Berruti A, Billé A, Lausi P, Levra MG, Giardino R, Ardissone F: Malignant pleural mesothelioma: clinicopathologic and survival characteristics in a consecutive series of 394 patients. Eur J Cardiothorac Surg 2008;33:307-313.

28 Herndon JE, Green MR, Chahinian AP, Corson JM, Suzuki Y, Vogelzang NJ: Factors predictive of survival among 337 patients with mesothelioma treated between 1984 and 1994 by the Cancer and Leukemia Group B. Chest 1998;113:723-731.

29 Spirtas R, Connelly RR, Tucker MA: Survival patterns for malignant mesothelioma: the SEER experience. Int J Cancer 1988;41:525530.

\$3 Moore AJ, Parker RJ, Wiggins J: Malignant mesothelioma. Orphanet J Rare Dis 2008;3 34-38.
31 Manzini PV, Brollo A, Franceschi S, Matthaeis M, Talamini R, Bianchi C: Prognostic factors of malignant mesothelioma of the pleura. Cancer 1993;72:410-417.

>32 Gonlugur TE, Gonlugur U: Pleural fluid findings as prognostic factors for malignant pleural mesothelioma. J Clin Lab Anal 2008; 22:334-336.

-33 Gottehrer A, Taryle DA, Reed CE, Sahn SA: Pleural fluid analysis in malignant mesothelioma. Prognostic implications. Chest 1991; 100:1003-1006.

34 Koch A, Fohlin H, Sörenson S: Prognostic significance of C-reactive protein and smoking in patients with advanced non-small cell lung cancer treated with first-line palliative chemotherapy. J Thorac Oncol 2009;4:326332.

35 Wilop S, Crysandt M, Bendel M, Mahnken AH, Osieka R, Jost E: Correlation of C-reactive protein with survival and radiographic response to first-line platinum-based chemotherapy in advanced non-small cell lung cancer. Onkologie 2008;31:665-670.

36 Hara M, Matsuzaki Y, Shimuzu T, Tomita M, Ayabe T, Enomoto Y, Onitsuka T: Preoperative serum C-reactive protein level in nonsmall cell lung cancer. Anticancer Res 2007; 27:3001-3004.

>37 Metintas M, Ucgun I, Elbek O, Erginel S, Metintas S, Kolsuz M, Harmanci E, Alatas F, Hillerdal G, Ozkan R, Kaya T: Computed tomography features in malignant pleural mesothelioma and other commonly seen pleural diseases. Eur J Radiol 2002;41:1-9.

-38 Kawashima A, Libshitz HI: Malignant pleural mesothelioma: CT manifestations in 50 cases. Am J Radiol 1990;155:965-969.

>39 Scherpereel A, Lee YC: Biomarkers for mesothelioma. Curr Opin Pulm Med 2007;13: 339-443. 